\begin{tabular}{|c|c|c|}
\hline $\begin{array}{l}\text { RESEARCH } \\
\text { ARTICLE }\end{array}$ & $\begin{array}{r}\text { ADVANCE RESEARCH JOURNALO } \\
\text { Volume } 11 \mid \text { Issue } 2 \mid \text { December, } 2020 \mid 57-60\end{array}$ & $\begin{array}{l}\text { SOCIAL SCIENCE } \\
\text { ISSN-0976-5611 }\end{array}$ \\
\hline $0=$ & DOI: 10.15740/HAS/ARJSS/11.2/57-60 & Visit us : www.researchjournal.co.in \\
\hline
\end{tabular}

\title{
Adolescent HIV/AIDS: Knowledge is a must
}

Shikha Kalra

Department of Human Development and Family Studies, College of Home Science (SKRAU), Bikaner (Rajasthan) India (Email : 18.skapoor@gmail.com)

\section{ARTICLE INFO :}

$\begin{array}{lll}\text { Received } & : & 15.07 .2020 \\ \text { Revised } & : & 24.08 .2020 \\ \text { Accepted } & : & 23.09 .2020\end{array}$

KEY WORDS : HIV/AIDS, Knowledge

HOW TO CITE THIS ARTICLE : Kalra, Shikha (2020). Adolescent HIV/ AIDS: Knowledge is a must. $A d v$. Res. $J$. Soc. Sci., 11 (2): 57-60, DOI: 10.15740/ HAS/ARJSS/11.2/57-60.Copyright@ 2020:Hind Agri- Horticultural Society

*Author for correspondence

\begin{abstract}
HIV/AIDS is a major threat to India. The number of people living with the disease is approaching 5 million. Global research shows that HIV/AIDS has direct links with health, social, psychological as well as economic problems by minimizing life expectancy, increasing burden on health care system, losing status in society and increasing inequality. India has the third largest HIV epidemic in the world, with 2.1 million people living with HIV. HIV/AIDS is a new phenomenon in the society. Misconceptions about HIV/AIDS abound worldwide. Female adolescents face even greater risk for STD transmission than their male peers and older adult women. Hence, the present study was undertaken to assess the gain in knowledge of adolescent girls after exposure to educational programme on selected four aspects of HIV/AIDS i.e. knowledge about adolescent years, information related to reproductive organs and physical changes, information related to HIV/AIDS, preventive measures for HIV/ AIDS (Individual and social responsibilities towards the person infected with HIV). The total sample for present study was consisted of 60 randomly selected adolescent girls belonging to nuclear families and low income group and studying in 10th, 11th, and 12th standards (15 to 18 years of age) of two randomly selected Government Senior secondary Girls Schools of Bikaner city, Rajasthan. The research design used for the present study was one group pre-test-post-test action research. The programme was planned on the basis of the results of pre test. Then, the results of post-test were obtained through the same duly pre-tested questionnaire cum interview schedule which was used during pre test. Frequency, percentage values and paired t-test was applied to see the significant difference between pre test and post-test scores of knowledge. The total sample had highest gain in knowledge (50.75\%) in aspect 3 (Information related to HIV/AIDS). The subject had highly significant gain in knowledge at $1 \%$ and $5 \%$ level of significance. The adolescent girls of class $10^{\text {th }}$ had the highest gain in knowledge i.e. $47.9 \%$ among the group. The major findings revealed the positive and definite impact of educational programme in improving knowledge about HIV/AIDS and to avoid discriminatory treatment to AIDS patient in employment providing services and other benefits.
\end{abstract}

